\title{
Transformações no trabalho, luta operária e desenraizamento: a reestruturação produtiva no cotidiano e nas representações de trabalhadores metalúrgicos de uma empresa da região do $\mathrm{ABC}$
}

\author{
Alice McCaffrey Busnardo ${ }^{2}$
}

\begin{abstract}
O artigo aqui apresentado é resultado de uma pesquisa cujo objetivo principal foi descrever e analisar as formas pelas quais a reestruturação produtiva (RP) é percebida pelos trabalhadores de um setor produtivo amplamente afetado por essas transformações. Para realizá-la optamos por um estudo de caso. Foram feitas visitas exploratórias à empresa-caso a partir das quais elaboramos diários de campo, ao que se seguiu o recolhimento de treze depoimentos de alguns dos trabalhadores. Do resultado de nossa análise podemos destacar alguns pontos: 1) A RP é compreendida de diferentes formas e acompanhada por diferentes sentimentos (que passam pelo alívio, pela necessidade de explicação, mas também pela desconfiança);2) É possível afirmar que os operários valorizam em grande medida algumas das mudanças introduzidas; 3) A reorganização do ambiente da fábrica, acompanhada de um discurso ideológico sedutor, camufla contradições estruturais e dificulta a visibilidade dos verdadeiros determinantes da insatisfação operária. O sistema participativo parece amparado por um controle internalizado e simbólico, que provoca a ilusão de uma coincidência entre interesses operários e empresariais; 4) A RP provoca a diluição do sentimento de classe e o embotamento da comunidade operária, que por sua vez minam a resistência e reinstauram o desenraizamento do trabalhador. 5) Há diferentes modalidades de enfrentamento entre os trabalhadores, as quais parecem relacionadas à história vivenciada por cada um, especialmente no que se refere à ligação com movimentos de organização coletiva.
\end{abstract}

Palavras-chave: reestruturação produtiva, trabalhador metalúrgico, luta operária, dezenraizamento, ideologia.

\section{Introdução}

Dara Corrêa (1997), "a reestruturação produtiva e industrial consiste em um processo que compatibiliza mudanças institucionais e organizacionais nas relações de produção e de trabalho, bem como a redefinição de papéis dos estados nacionais e das instituições financeiras (...), visando atender às necessidades de garantia de lucratividade. Nesse processo, a introdução das novas tecnologias informatizadas tem desempenho fundamental". (p. 202). As transformações advindas da reestruturação produtiva implicam tanto a estrutura produtiva de forma global, quanto a atividade de trabalho nas fábricas.

De fato, essa nova forma de organização vem acompanhada de mudanças que se desenrolam num cenário maior (fora do espaço da fábrica propriamente dito), envolvendo especialmente sérias alterações na estrutura mundial de produção, mas é também fortemente

\footnotetext{
${ }^{1}$ Este artigo é parte de uma pesquisa realizada em 1999 como atividade de estágio em psicologia social do trabalho no Centro de Psicologia Aplicada ao Trabalho do Instituto de Psicologia da Universidade de São Paulo. Além da autora, participaram mais ativamente do projeto: Isabella Paiva Ribeiro, Maira Alves Barbosa e Luciana Stoiani. Supervisor: Fábio de Oliveira.

${ }^{2}$ Instituto de Psicologia da Universidade de São Paulo.
} 
marcada por mudanças significativas no "chão de fábrica", as quais interferem e determinam as condições de trabalho imediatamente vivenciadas pelos trabalhadores.

Tais transformações se expressam por vezes de modo mais explícito (com a introdução de máquinas, equipamentos e outras formas de organização do processo de trabalho), mas também de maneira mais sutil, através da proposição de novas políticas de gestão de pessoas e da hipertrofia do controle simbólico.

Mediante esse novo contexto, é possível dizer que a atitude dos trabalhadores não pode ser descrita como simplesmente passiva, mesmo quando o processo de reestruturação produtiva se mostra poderoso e dominante. Os trabalhadores têm apresentado respostas para os problemas com os quais se defrontam e esse enfrentamento se dá tanto no plano sindical, quanto no próprio chão de fábrica, no dia-a-dia de trabalho.

Foi justamente com o intuito de compreender como esse enfrentamento estaria presente no cotidiano das fábricas que nos propusemos esta pesquisa. Como então o trabalhador percebe as transformações ligadas à reestruturação produtiva? Como elas atingem seu cotidiano? Como lida com elas? Se existem modalidades de enfrentamento, de que forma e onde elas aparecem? Imaginamos que, esboçar algumas respostas a essas perguntas poderia, em alguma medida, fornecer subsídios para combater a paralisia diante das novas tecnologias e das incertezas que rondam o mercado de trabalho.

Para realizar tal tarefa, amparamo-nos na idéia de que o estudo dos discursos e das práticas cotidianas quase sempre é facilitado pela opção metodológica de estudos de caso. Isso porque se trata, especialmente no momento de um estudo exploratório, de investigar, não a distribuição de um conjunto de idéias no imaginário de uma população específica, mas sim os processos de constituição dessas idéias e representações.

A coleta de dados se deu a partir de visitas exploratórias à empresa-caso, as quais serviram de base para a definição de setores nos quais foram feitas observações e entrevistas. Foram recolhidos treze depoimentos, cada um contando com aproximadamente cinquenta minutos de duração. Para sua realização foi elaborado um roteiro que, por sua vez, foi posteriormente testado por meio de uma entrevista-piloto.

As entrevistas foram gravadas e transcritas e os dados de observação registrados em diário de campo. Todas essas informações foram utilizadas de modo a não identificar as pessoas, pois o nosso interesse era conhecer as idéias que circulam entre os trabalhadores e não opiniões particulares.

De posse dos dados coletados, realizamos uma organização do material e finalmente uma análise do mesmo. Nossa análise amparou-se na delimitação dos temas presentes nos discursos, na identificação das concepções acerca dos vários tópicos que constituem a reestruturação produtiva e na descrição das práticas cotidianas relacionadas ao tema. Ênfase especial foi conferida às estratégias de enfrentamento e mudanças.

\section{Um imaginário sobre as mudanças: do chicote à conversa}

Como já mencionamos anteriormente, as novas formas de gestão de pessoal propostas pelo sistema toyotista, invadiram o cotidiano de trabalho dos operários e estabeleceram dinâmicas e relações inusitadas. Surpresos com a súbita mudança no padrão de comportamento dos chefes e ao mesmo tempo abalados pela notícia de que eles mesmos poderiam e deveriam tomar parte ativa no trabalho, os trabalhadores se dividem entre o 
alívio, a necessidade de explicação para uma mudança tão abrupta e, em alguns casos, a desconfiança de que essas alterações não sejam reais e verdadeiramente benéficas.

Referindo-se ao antigo regime, os depoentes relatam que não tinham direitos respeitados e que não havia qualquer liberdade de expressão. Cada passo era programado e enunciado pelo chefe: a máquina na qual deveriam trabalhar, a tarefa que deveriam efetuar, o tempo da tarefa (quando deveriam parar, quando deveriam movimentar-se e em que ritmo). Nenhuma palavra do mestre ou do supervisor poderia ser questionada.

Como operários, encontravam-se submetidos a duras regras de comportamento. Entravam na fábrica para trabalhar exatamente como prescrito por seus superiores, tendo como certo e obrigatório, em cada função, o cumprimento de ordens. Ao comando que recebiam, não podiam manifestar qualquer desacordo ou insatisfação, apenas obediência. Desta época, lembrada como a época do chicote, os depoentes guardam a memória da desconsideração, da opressão e da humilhação ostensivas. Assim nos contam dois depoentes, João Augusto e Rodrigão ${ }^{3}$, ambos trabalhando há mais de quinze anos nesta fábrica:

E a produção era puxada e chefia era, a gente fala, modo de falar do peão, é chicote mesmo, forçado mesmo, não tinha moleza não. Era cheio de briga. Não tínhamos Comissão de Fábrica, né. (...) Então, esse período antes da Comissão de Fábrica, apesar que já tínhamos Sindicatos, mas nós não tínhamos voz ativa aqui dentro. (...) Ou você fazia ou você ficava manjado, entendeu? Se você ficasse manjado, no primeiro corte você perdia o emprego. Hora extra também, não era negociado, era forçado a fazer hora extra. Então, nós tínhamos uma salinha, metade disso aqui, lá embaixo, no Departamento Pessoal. O homem chamava Seu Antônio. Se você não viesse hoje, amanhã você tinha que ir lá falar com o Antônio. Aí, era cartão de ponto naquela época. O teu cartão não dava na chapeira, aí você tinha que conversar com esse cara. Esse homem ia telefonar para tua chefia e ia falar assim: como é que você chama mesmo? [Alice: Alice] Alice, então, era assim: "e a Alice, como é que ela é?", Aí eu ia falar: "Ah, a Alice... Ah, ela está dando umas mancadas aqui, está faltando". Aí, sem você saber, né, ele está falando com o chefe: "E aí, o que a gente faz?", "Ah, mete ele no gancho!". Entendeu, era assim. Entendeu? Às vezes você estava com uns problemas em casa, você não vinha, tinha que trazer atestado, às vezes você não conseguia atestado, se não trazia... Era assim. Tinha banheiro que tinha um buraco bem grande e a chefia vigiava, se demorasse muito no banheiro ia atrás. (...) Mas antigamente era bem cruel mesmo. Era linha dura (João Augusto).

Ah... a empresa era bem diferente do que é, muito diferente. Isso aqui, na verdade... Do tempo da ditadura, aqui a gente era mandado, tinha que fazer o que eles mandavam mesmo que tivesse errado. Você não podia falar nada, não tinha liberdade de expressão. (...) Com a chefia era uma coisa! Aonde você via... O funcionário via as coisa errada e não podia falar nada. Então, como eu disse antes, era a época da ditadura, a própria chefia também eram os ditador, que quando eles falava que tinha que ser daquele jeito e você tinha que fazer daquele jeito mesmo que fosse errado, não admitia que você falasse qualquer coisa ao contrário daquilo que eles estavam contando. Então você vivia de baixo de uma pressão, não é, fazer o que eles querem, não tinha diálogo (Rodrigão).

Em oposição à época do chicote, os depoentes falam sobre o momento atual: os dias da conversa. Apontam que a marca da relação entre operários e chefes, nos dias de hoje, parece ser, inegavelmente, a comunicação. As relações de trabalho no interior da fábrica passam a ser mediadas pelo diálogo mais do que pelo monólogo constante dos dirigentes. Nestes diálogos, o operário vê restituído, em alguma medida, o seu direito à voz: os trabalhadores podem agora dizer o que pensam a respeito do trabalho que realizam e são incentivados a dar sugestões sobre a melhor maneira de realizar uma tarefa. O comportamento dos chefes agora

\footnotetext{
${ }^{3}$ Os nomes citados nesse artigo, dos depoentes, pessoas citadas nos relatos e o da empresa em que foi realizado o estudo, foram alterados para preservar a identidade dos entrevistados.
} 
é outro: são obrigados a ouvir aquilo que os trabalhadores têm a dizer e devem cumprimentálos ao início de cada turno. Contou-nos um depoente:

Hoje não, hoje é muito diferente daquilo. Hoje o funcionário, hoje ele tem a mesma liberdade que tem o gerente, o chefe. Ele pode até falar com o gerente que aquilo está errado, pode disconcordar. Então tem diálogo hoje. (...) A gente jamais poderia pensar que eu pudesse chegar no meu mestre, no meu gerente e falar pra ele que eu disconcordava daquilo que estava sendo feito (Rodrigão).

O itinerário do operário no interior da fábrica não mais se resume a bater seu cartão e esperar em seu posto a ordem do chefe. Ao trabalhador é agora permitida a circulação pela fábrica - o que inclui acesso às salas da gerência -, assim como a participação em reuniões com superiores, nas quais se debatem os problemas internos e externos à produção: qual a melhor maneira de se realizar uma tarefa, qual o melhor posto para cada um ficar, como anda a concorrência no mercado, qual a situação comercial da empresa no contexto nacional. A troca de informações entre operários e chefes tornou-se, hoje, importante ingrediente das relações de trabalho.

Oh, a gente, antes, não tinha muito contato com chefe, não assim, né? Ele passava o serviço pra gente e pronto. Hoje em dia eles fazem reunião com a gente. Eles falam o que está acontecendo no mercado, o mês que vem o que vai sair, o que não vai, eles explica a real, qual que é. (...) Então, isso aí não tinha, a gente não sabia de nada. (...) Ah, às vezes chama a gente pra uma reunião, o pessoal tudo aí junto, conversa. Antes o chefe estava, o lugar dele era o escritório e a gente aqui, a gente não sabia de nada, num sabia se estava bom ou num estava, como que estava o mercado lá fora, se a gente estava vendendo bem, num estava, se precisava tanto de peça. Hoje em dia a gente sabe o tanto de peça que tem por mês, se vai pra sessão de vendas. A gente está por dentro das coisas (João Pedro).

No contexto das relações de trabalho, uma outra figura aparece representando um papel importante: o trabalho em grupo. Assim como no caso das novas formas de relacionamento entre chefes e operários, o chamado team work faz parte das diretrizes propostas pelo sistema de produção enxuta (Bresciani \& Oda, 1996; Ferro, 1990; Trist, 1978). Visando um melhor aproveitamento da mão-de-obra e do tempo de execução de cada tarefa, a empresa propõe que os trabalhadores passem a se organizar em pequenos grupos (compostos por cinco a oito operários em média) responsáveis pela realização de uma etapa da produção. Apoiado na concepção de que conceder maior autonomia, responsabilidade e autoridade a um pequeno grupo de operários representaria um fator de incremento da produtividade e da lucratividade, o trabalho em grupo instaura um novo tipo de interação entre os próprios operários. Decidir sobre como solucionar um problema surgido no processo de trabalho ou até mesmo sustentar uma posição divergente da posição da mestria, tornam-se elementos constituintes do novo modelo da atitude operária.

O trabalho em grupo é, para os operários, uma figura contraditória. Trocar informações e combinar com os próprios companheiros como uma tarefa será realizada, saber melhor como acontece o processo total de produção de uma peça, perguntar para o colega se ele pode substituí-lo em um dia em que terá que faltar, discutir com o porta-voz $z^{4}$ que é também um operário - quando as férias podem ser tiradas e, talvez, mais do que tudo, poder efetuar um rodízio de tarefas ao invés de permanecer sempre realizando o mesmo e contínuo movimento; tudo isso contribui para que o trabalho se torne menos monótono, mais

\footnotetext{
${ }^{4}$ Com a organização na forma de pequenos grupos, surge no interior das relações de trabalho a figura do porta-voz. Eleito a cada seis meses pelo próprio grupo do qual faz parte, o porta-voz possui a função de coordenação das atividades de trabalho. É também com ele que se passa a discutir a questão das faltas, atrasos e férias. Poderia ser considerado uma espécie de supervisor, na medida em que se torna o primeiro responsável pelos resultados que aquele grupo é capaz de alcançar.
} 
dinâmico, até mesmo menos rígido. A valorização do trabalho em grupo não é rara nos depoimentos:

(...) Ah, o diálogo entre duas pessoas. Sentar nas mesas que nós temos lá pra conversar. Nunca acontecia isso. E o serviço, se vem errado, você vai lá e explica, avisa: oh, fulano, está faltando isso. Antigamente não, que se dane o outro, eu não quero nem saber, eu tenho que fazer o meu serviço. Hoje não. Você se preocupa com o seu serviço e com o do seu companheiro. Melhorou bastante. Que nem, a amizade ficou melhor, os diálogos, melhorou cem por cento. Todo mundo está se unindo. (...) Agora o pessoal está, como se diz, mais maduro, né? Ficou fácil pra qualquer coisa, todo mundo se interessa um pelo outro, pelo serviço, a colaboração (Ronaldo).

Era bem diferente de hoje. Logo quando eu entrei aqui, a gente era bitolado a trabalhar só em uma máquina. Então dificilmente você estaria fazendo o que nós faz hoje aí. Você trabalhava numa máquina e era só aquela máquina mesmo, num dava oportunidade pra gente estar trabalhando em outras máquina. (...) E esse sistema de rodízio também que a gente está fazendo, também é muito bom. (...) Então, ficou melhor, porque fazer um serviço repetitivo... Inclusive é até bom pra saúde, já pensou você ficar numa máquina só fazendo aquela função, aquela função direto? Cansa muito (Edvaldo).

(...) Antigamente você entrava pra trabalhar numa máquina e ficava ali, cinco, seis anos, só fazendo aquele trabalho repetitivo. Inclusive isso afetava a saúde do trabalhador. (...) E a partir do momento que a gente começou a trabalhar revezando de máquina, começou a desaparecer esses problemas. Então essa parte ai melhorou. Uma parte que melhorou também foi a união do grupo. A gente começou a se entender mais, não tinha mais divergência. Existe às vezes uma, algumas coisinhas, mas a gente supera porque a gente imediatamente convoca uma reunião (Josias).

Entretanto, nada disso dilui outra face do trabalho em grupo, aquela marcada pela sobrecarga de tarefas, pela tensão advinda do excesso de responsabilidade e pela aceleração do ritmo de trabalho. Como nos disse um operário:

(...) O meu medo é que eles se percam nesse meio e achem que o ser humano tem que fazer tudo sozinho, num só. E aí, sobrecarregue demais esse ser humano e ele venha a cair numa estafa total. Porque ele não vai abrir mão do que ele está fazendo ali pra dizer que não dá. Ele vai tentar fazer. E o meu medo é que nessa daí... Caia numa depressão ou alguma coisa desse tipo, porque é muito sobrecarregado. Porque o nível de emprego hoje em dia está muito escasso. Então, quem tem ele, vai brigar pra ocupá-lo (José).

Em uma reunião que tivemos com um dos encarregados da política de recursos humanos na empresa, ouvimos que o resultado de uma enquete feita com os trabalhadores, a respeito do trabalho em grupo, indicava que a maioria era da opinião que o volume de trabalho havia aumentado após a instalação dessa forma de organização. $\mathrm{O}$ que chamou nossa atenção foi a interpretação, talvez um pouco simplista, feita por esse mesmo diretor: em sua opinião, a queixa do volume aumentado de trabalho deveria corroborar a hipótese de que os funcionários estariam insatisfeitos; no entanto, segundo ele, surpreendentemente a grande maioria preferia continuar com o trabalho em grupo.

Avessos a um regime que fazia uso ostensivo da força, os operários não querem deixar escapar esse limitado, mas significativo alívio, trazido por essas formas mais maleáveis de relação, agora presentes no cotidiano da fábrica. Como desprezar a possibilidade de expressar-se minimamente, de participar de alguma forma com suas próprias opiniões, de conhecer um pouco mais do trabalho que se realiza? Que ser humano recusaria tais concessões? 
O poder de sedução exercido por esse novo regime é grande exatamente porque ele vai ao encontro de necessidades já tão insistentemente reivindicadas pelos próprios operários. O trabalho operário, especialmente depois da instauração dos padrões tayloristas de produção, sempre foi um trabalho marcado pela violência dos superiores, pela fragmentação da tarefa, pela repetição interminável, pelo desconhecimento do processo, pela exigência de absoluta obediência e submissão. E é exatamente nesses aspectos tão distintivos do trabalho subalterno e insalubre que a reestruturação produtiva vem interferir. São propostas maior participação, autonomia, conhecimento do processo de trabalho e diálogo. Resistir e reivindicar nas mesmas bases anteriores se tornou algo estranho, de significado às vezes perdido, já que a fábrica e os patrões parecem finalmente ter assimilado as exigências operárias e respondido às suas demandas.

O ambiente da fábrica, as palestras de "conscientização" do sistema participativo, os cursos de treinamento, a chance de maior escolarização, o comportamento cordial dos chefes, até mesmo nosso desejo bastante legítimo de que o trabalho operário tenha deixado de ser algo tão aversivo e humilhante: tudo isso nos carrega para a direção da comemoração da reestruturação produtiva. No entanto, com apoio nos mesmos depoimentos que por vezes parecem somente valorizar o novo sistema e no aprofundamento de nossas impressões das visitas à fábrica nos sentimos exigidos a problematizar algumas questões. Gostaríamos de entender mais e melhor: que participação e que diálogo são esses? Quais as consequências dessas relações mais maleáveis entre chefes e operários?

\section{Que diálogo e que participação? O controle simbólico e ideológico}

A chance de falar e até mesmo de brigar com chefes, de circular pela fábrica e participar de reuniões em que se discutem o processo e o destino de produção, de levantar opiniões e apontar sugestões - toda essa nova "abertura" da empresa segue aquela mesma lógica que fundamentou a concessão de autonomia e responsabilidade ao grupo de trabalho: a lógica da lucratividade. A autoridade está agora mais associada à competência e à qualidade: quem fala e comanda é quem tem argumentos produtivos ao seu lado. O operário pode discordar e até mesmo prevalecer sobre seu mestre se ao fazê-lo estiver buscando maior qualidade. O poder concedido ao grupo de trabalho é na verdade a voz da produtividade que fala agora através dos próprios operários. Assim nos mostrou com evidência um operário entrevistado:

(...) Porque se o grupo foi formado pra ter uma autonomia, vamos dar um andamento, não vamos? Ele já não, ele que queria mandar. É o que eu estou te falando, a cabeça dele era dura. E um dia, no final do ano, eu lembro como se fosse hoje... Parece que entrou uma cabine, um canavieiro. [Alice: Um modelo?] É, um modelo. Aí não tinha revestimento traseiro e eu parei ali. E ele falou: "Por que você parou aî?", "Porque está faltando peça". "Então solta". Eu falei: "Não vou soltar!". "Solta!". Eu falei: "Não vou, quero ver quem vai fazer eu soltar; o grupo decidiu e não vai soltar". "Ah, então, eu vou atrás disso". "Então, o senhor vai". Aí ele foi, depois ele veio e falou: "É, não tem a peça, mas tem essa". Eu falei: "Essa eu não vou montar porque é errado" "É, mas eu estou mandando". Eu falei: "Eu também estou mandando, eu e o grupo, sem o grupo eu não posso fazer nada, o senhor concorda?". "É, mas eu não sei o que". "Não, o senhor não vai teimar comigo". Aí ele falou: "Então eu vou atrás do AQF". Eu falei: "Vai". Aí o cara do AQF disse: "Não, o montador está certo. Vamos ver um superior pra ver se dá montagem". Aí, depois deu mais um tempo, ele veio e falou: "O cara liberou e falou que pode fazer assim. Dá pra você montar aquele carro?" Eu falei pra ele: "Eu já falei para o senhor que eu não vou montar porque o grupo não vai concordar". Isso foi em outubro pra 
novembro, eu falei pra ele: "Não tem acordo, nós já estamos na terceira linha". O grupo decidiu e não montou (Ronaldo).

Dialogar, no interior da fábrica, não visa exatamente a troca de pontos de vista entre duas partes em busca de um acordo. O tema já está definido, assim como o resultado da conversa. Trata-se mais de um jogo, onde ganha quem mais rapidamente atingir o objetivo: a solução eficiente para um problema da produção. É bom lembrar que o objetivo em questão é proposto extrinsecamente e não por quem enfrentará intempéries e infortúnios para alcançálo. Podem os operários colocar questões e sugestões que representem uma melhoria das condições de trabalho, mas que ao mesmo tempo não atendam às exigências de produtividade ${ }^{5}$ Mais uma vez, não se trata de desvalorizar por completo algo tão caro aos trabalhadores e a qualquer um (a possibilidade de expressar-se), mas sim de enfatizar o uso que é feito de uma necessidade humana. Assim nos disse um depoente, ao refletir sobre o conflito em que se viu confinado simplesmente por ceder ao desejo de participação:

(...) Mas eu fui em frente [refere-se ao fato de ter retomado os estudos]. Daí começou a sair as mudanças. Aí me convidavam, né? Pra mim participar. Daí eu recebi muitas críticas do pessoal, as pessoas não entendiam. Achavam que eu estava... "Ah, pô, você está saindo para o lado da empresa". Não, nada disso. Aí começou pressão daqui, pressão dali, às vezes as pessoas vinham, me pressionavam. O próprio meu colega me entregava pra representação. A representação vinha assim: "Oh Leonardo, o que você está fazendo?". Eu falava: "Eu não estou fazendo nada! Eu apenas estou... Se eu for convidado, eu vou. Igual vocês me convidam pra participar do Sindicato, aqui também, eu vou! Eu quero participar!" (Leonardo).

Antunes (1999) considerou que o chamado sistema participativo seria melhor definido pela expressão envolvimento manipulatório. Diálogo, participação, autonomia, responsabilidade, são experiências que na prática aparecem distorcidas porque desviadas de seu sentido original. Todos esses termos, que em sua essência caracterizariam o início do desmonte do trabalho alienado, se configuram na realidade num mascaramento de posições estruturais, ainda vigentes e talvez radicalizadas pela falta de visibilidade. $\mathrm{O}$ operário que passa a ver em seu trabalho sua marca e a de seus colegas de grupo, que enfrenta o chefe na defesa de um procedimento que julga mais eficiente, está na realidade defendendo os interesses da própria empresa. Os conflitos são transferidos para o âmbito restrito do chão de fábrica e versam quase que exclusivamente sobre a necessidade de qualidade e produtividade. O processo de trabalho poderia logo dispensar a figura do chefe, já que progride muito melhor apoiado no controle internalizado. Nas palavras de Antunes:

Fundamentalmente, essa forma de produção flexibilizada busca a adesão de fundo por parte dos trabalhadores, que devem assumir o projeto do capital. Procura-se uma forma daquilo que chamei de envolvimento manipulatório levado ao limite, em que o capital busca o consentimento e a adesão dos trabalhadores, no interior das empresas, para viabilizar um projeto que é aquele desenhado e concebido segundo seus fundamentos exclusivos. Trata-se de uma forma de alienação ou estranhamento que, diferenciando-se

\footnotetext{
${ }^{5}$ Tivemos a chance de participar de uma reunião entre todos os porta-vozes, mestres, supervisores e o diretor da seção. Trata-se do espaço oficialmente instaurado para o diálogo e que acontence periodicamente. Entretanto, pudemos observar que os operários sentiam-se bastante intimidados e poucos realmente participavam. Além disso, os próprios coordenadores da reunião deslegitimavam as falas dos trabalhadores, argumentando que a reunião possuía somente um caráter de verificação de prazos e de realização de tarefas, onde portanto não havia tempo ou espaço para a discussão de problemas. A conversa girava novamente em torno da necessidade de treinamento e de eficiência na produção. As exigências operárias ou eram prontamente negadas por "falta de condições" ou então burocratizadas e transferidas para um outro fórum. Em um outro encontro que tivemos com o diretor responsável pela área de recursos humanos, ouvimos que de fato a maioria das sugestões propostas pelos funcionários não são implantadas porque são consideradas inadequadas.
} 
do despotismo fordista, leva a uma interiorização ainda mais profunda do ideário do capital, avançando no processo de expropriação de savoir faire do trabalho (p. 190).

$\mathrm{Na}$ intenção de, combinadamente, solucionar o problema da resistência operária que vinha crescendo e criando dificuldades - e criar um novo sistema produtivo que correspondesse às exigências do atual cenário de competitividade e consumo ${ }^{6}$, o sistema toyotista fornece aos trabalhadores a ilusão da coincidência entre seus próprios interesses e os da empresa. Cria-se, de um lado, uma situação amistosa com aqueles a quem explora, através de uma aparente cortesia que amortece os ânimos de revolta e alivia, especialmente porque comparado a um tempo de brutalidade explícita:

(...) Eu achei bom porque [refere-se ano novo comportamento dos chefes]... A gente via o chefe assim, que nem eu falei pra você: o cara estava no escritório, então você não tem contato com ele. Então eu acho importante o cara fazer uma reunião com a gente. (...) Eu acho importante que ele está se interessando por nós, pelo serviço (João Pedro).

Simultaneamente efetiva-se a apropriação do conhecimento e das habilidades cotidianas e coletivas dos trabalhadores, que, confusos sobre sua posição no interior da organização fabril (já que se proclama a abolição das hierarquias), aprimoram-se e desgastamse em seu trabalho sem aquela antiga evidência de estar sendo expropriados. O conflito de interesses é constantemente camuflado e o anseio operário não é mais enfaticamente lutar por seus direitos, mas concentra-se na conquista de elogios e valorização de sua competência:

(...) Eu estou aqui pra trabalhar com qualidade, não com porcaria. Mudou hoje, não é mais gambiarra. Hoje é cem por cento qualidade. Porcaria o grupo não vai fazer, ninguém vai assumir. Porque se o grupo fizer uma porcaria, quem vai assinar primeiro? O porta-voz, não é? E depois o grupo (Ronaldo).

(...) Quando a Luciana entrou aí - eu converso muito com ela, né - ela falou: "Poxa, Ronaldo, falaram do seu currículo aqui, você é totalmente diferente". Eu falei: "Mas por quêe?" "Nossa, tudo que vai fazer, você é o primeiro, você é o cabeça, na lista pra mandar pra qualquer lugar emprestado". O Renan ficou admirado também: "Eu não tenho problema com você, cara. Não tenho. Você trabalha certo, você sempre está aí, trabalha onde mandam, se mandam vir um sábado ou um domingo ou qualquer hora, você vem. Então eu não tenho o que falar de você" (Ronaldo).

De fato, temos a impressão de que a figura do chefe, ou do mestre, tende a desaparecer das linhas de montagem. No entanto, parece mais correto afirmar que vem ocorrendo uma despersonalização do papel do supervisor que passa a operar internamente, na subjetividade do próprio operário, através da interiorização do controle. Insultos verbais, ordens infinitas, humilhação pública, ameaças explícitas de demissão: nada disso é mais necessário. Os próprios operários, tomados pela confusão que o novo regime provoca, aderem com unhas e dentes às metas de produtividade e qualidade e se auto-regulam segundo normas que são exteriores, mas encontram-se disfarçadas de próprias.

Essa forma de autoritarismo, que não carrega o ingrediente da força explícita presente no antigo regime, parece coincidir com aquilo que Marilena Chaú́ (1979)

\footnotetext{
${ }^{6}$ Estratégias que somadas configuram, nas palavras de Ricardo Antunes, a resposta do capital à sua crise estrutural, que teve início nos anos 70 e tinha como causa, além da queda da taxa de lucros e da hipertrofia do sistema financeiro, o esgotamento do padrão de acumulação taylorista/fordista e o incremento da força operária organizada.
} 
descreveu como sendo o autoritarismo das elites. De base ideológica, essa "modalidade" de autoritarismo se constrói mediante uma equação entre a realidade e um determinado discurso a respeito dessa realidade, discurso que será próprio daqueles que pretendem, através dele, participar, constituir e fortalecer uma ordem de dominação econômica e social. Trata-se do meio pelo qual a estrutura dominante procura mascarar conflitos e diferenças de forma a criar uma falsa idéia de igualdade política e de homogeneidade das condições sociais, mantendo assim um estado de coisas que, na realidade, responde apenas aos interesses de alguns. Nas palavras da própria autora:

(...) se para exercer o poder e justificar seu exercício os dominantes precisam que as representações acerca do social e do político coincidam com o real e se, neste, povo e elite constituem pólos contraditórios da divisão e luta de classes, os dominantes precisam agir de sorte a fazer com que todas as manifestações da diferença e da contradição permaneçam escondidas graças a um discurso e a uma prática coercitivos que garantam a todos os membros da sociedade o sentimento de que fazem parte dela da mesma maneira e que a contradição não existe, ou melhor, seja vista como diferentes maneiras igualmente legítimas de fazer parte da mesma sociedade. (...) O autoritarismo existe sempre e cada vez que as representações e normas pelas quais os agentes sociais e políticos interpretam suas relações sejam representações e normas vindas do exterior e do alto (pp. 120-121).

O autoritarismo não foi extinto do cotidiano de trabalho dos operários, ele apenas encontrou uma modalidade de apresentação menos explícita, no entanto, mais eficiente e, por outro lado, talvez mais danosa para os que permanecem sob seus comandos. Envolvidos por esse discurso e essa prática coercitivos - que pregam a idéia de um sistema participativo, a igualdade entre chefes e metalúrgicos e a sugestão de que o trabalhador agora é "dono" e responsável pelo que produz -, os operários acabam por vezes cedendo a interpretações e idéias que não advém de sua própria experiência ou da de seu grupo, mas são exatamente impostas de fora e de cima. O trabalhador se torna seu próprio patrão, quase sem se dar conta de que sua prática mesma mantém as bases de uma falsa igualdade e sustenta uma estrutura que não prevê a erradicação de condições de fato assimétricas. Por que pensar como os donos da empresa pensam - "precisamos ter qualidade senão perdemos a concorrência; precisamos aumentar nossos índices de lucratividade; precisamos trabalhar mais horas, no fim-de-semana se for necessário" - se na realidade eles não são donos de nada? Cria-se uma teia da qual é difícil se soltar exatamente porque todas as idéias e justificativas se amarram na formação de um corpus de representação homogêneo, que coloca patrões e subalternos em posições igualmente legítimas e cria uma situação de invisibilidade das contradições e, nessa medida, de invisibilidade da exploração da força de trabalho.

\section{Deslocamento do conflito: operário versus operário}

Essa venda que é colocada sobre os olhos dos trabalhadores pela manipulação autoritária e ideológica das representações, promove o que identificamos como deslocamentos e desvios de interpretação. De um lado, dado o fato de que a despersonalização da figura do chefe não torna o trabalho uma atividade realmente cooperativa e não hierarquizada, uma vez que as metas de produção continuam sendo

\footnotetext{
${ }^{7}$ Durante aquela mesma reunião periódica de equipe, tivemos a chance de presenciar a seguinte fala de um diretor: "O problema é que eles [os operários] não conseguem pensar como donos!" Ele se referia à dificuldades na instalação de novas formas de organização que exigiam autonomia e responsabilidade dos funcionários.
} 
determinadas extrinsecamente, os conflitos antes polarizados por chefes e operários passam a se dar no interior do grupo de trabalho, entre os próprios operários ${ }^{8}$. Júlio, um dos operários entrevistados, que na época ocupava a posição de porta-voz, contou-nos que esse papel era por vezes muito incômodo: seu colegas questionavam suas atitudes, responsabilizavam-no pelos erros, não colaboravam com ele. Sendo o porta-voz um representante do grupo - como o próprio nome define -, como pode o grupo não colaborar com ele? Vale um trecho de seu depoimento:

(...) Eu acho que de 100\%, acho que 80\% é assim. Eu acho que todos os grupos. Eu vejo nos outros também. Não colaboram muito com o porta-voz. O porta-voz às vezes fala uma coisa, eles acham que está errado. Mas o porta-voz tem ordem da chefia pra fazer aquilo. E ele tem que fazer aquilo. Agora, se o grupo não concorda, o grupo tem que falar na hora. Aí o portavoz vai no mestre e fala: "Não dá certo, o grupo não quer". Mas se eles não fizer isso, na hora, assim, falar um não, pra mim vai estar tudo bem, vou chegar no mestre e vou falar assim: "O grupo aceitou". E depois de tudo, que aceitou, é que eles vão meter o pau no porta-voz, falam que o porta-voz errou, que não sei o quê, sabe? (Júlio).

O porta-voz, na opinião dos outros trabalhadores, não parece estar ocupando exclusivamente a função de representante do grupo. Por que é preciso esconder algo dele? Uma contradição se estabelece: ao mesmo tempo em que ele continua sendo um operário como os outros, o porta-voz parece receber, talvez involuntariamente, atributos de chefe. Quem errou não foram os superiores que ordenaram que se fizesse algo em desacordo com o grupo, foi o porta-voz. Está feito o deslocamento: o conflito não é mais com o chefe, é com o porta-voz. Os pólos do embate se tornam: operários de um lado e representante de operários do outro. Num outro ponto, um desvio muito semelhante parece acontecer com relação à Comissão de Fábrica e ao Sindicato. Júlio e Rodrigão (operário aguerrido e ex-integrante da Comissão) assim relataram:

Então, eu acho que o Sindicato está fazendo uma campanha legal, não tenho queixas deles não. Só cobro bastante deles essa luta a respeito de salário-hora, da faixa salarial. Isso aí eu cobro muito deles e vou cobrar até quando estiver no nível certo do salário, depois não. Depois eu só vou cobrar no futuro, se isso não estiver acabado pro meu filho ou pra minha filha que entrar aí, se fosse trabalhar na Empresa, né? Se não tiver mudado ainda, se eu estiver trabalhando aqui, eu vou continuar cobrando deles pra isso acabar. Porque eu acho que isso é coisa errada. (...) Então, eu acho que em relação a isso eu vou sempre cobrar eles. E eu chamo e falo mesmo na cara da pessoa. Eu, o que eu tenho que falar, eu falo: "Eu acho que está errado, eu acho que vocês tinham que ter na pauta quando vocês fossem discutir na reunião, ter visto isso". (...) Era a coisa mais certa a fazer. Aí eles disseram: "Pô, se a gente tivesse essa idéia!" Mas vocês passaram pra perguntar? Não passaram. Então a minha luta agora é pra isso. Agora, em relação à Empresa eu estou contente, gosto de trabalhar aqui, gosto de trabalhar na minha função (Júlio).

(...) A gente encontrou bastante barreira antes dessas mudança toda [refere-se à situações de conflitos anteriores ao surgimento da Comissão de Fábrica]. Era um quebra-pau danado, se punhava fogo em cabine. Mas aqui não; aqui, pra discutir a gente tem a Comissão. A briga nossa é contra a Comissão, quando você está com um problema e a Comissão vai lá e não se resolve. A gente acha que é má vontade. E aí a gente cobra duro, sério, da própria Comissão. A briga é com a Comissão (Rodrigão).

\footnotetext{
${ }^{8}$ Isso não contradiz o fato, também existente e apontado pelos depoentes, de que o trabalho em grupo atua na intensificação da cooperação e do auxílio entre os operários que trabalham juntos. No entanto, é bom lembrar que tanto a transferência do conflito para o interior do grupo, quanto a cooperação entre os trabalhadores traz bons resultados para a empresa: no primeiro caso, mantém-se a camuflagem e a distância do verdadeiro conflito - o conflito de classes - enquanto que, no segundo, obtemse ganho na produtividade, fruto de um trabalho mais harmonioso e orquestrado.
} 
A reorganização completa do ambiente da fábrica, que vem acompanhada de um discurso ideológico sedutor, camufla as contradições estruturais e dificulta a visibilidade para os verdadeiros determinantes da insatisfação operária. Entretanto, a insatisfação não desaparece: o salário está defasado', acidentes continuam acontecendo, assim como problemas de saúde ${ }^{10}$ e a sobrecarga de trabalho permanece, talvez até mesmo intensificada. Expostos à força de um discurso e de uma prática que sustentam a equivalência entre os interesses operários e os da própria empresa, os trabalhadores acabam por reconhecer em seus próprios representantes aqueles contra quem se deve lutar. Não é a empresa que não concede aumento, é o sindicato que não tem cumprido seu papel. Não são os patrões que não dão abertura para a instauração de órgãos de representatividade, é a Comissão Fábrica que não está agindo na defesa de seus direitos. Novamente, o conflito é deslocado para o âmbito exclusivo dos trabalhadores.

Aqui duas observações nos parecem relevantes: a primeira se refere à recente atuação do Sindicato e da Comissão de Fábrica. Não temos qualquer informação mais precisa que nos capacite a opinar sobre este ponto, é somente com apoio nos depoimentos que levantamos as seguintes questões: o Sindicato e Comissão têm estado realmente próximos ao chão de fábrica e às verdadeiras exigências dos trabalhadores? Se estão, qual a radicalidade de suas propostas? Tem havido excessiva ligação entre esses órgãos de representação operária e a própria empresa, de forma que as negociações não vêm atendendo tão profundamente aos anseios dos trabalhadores? Há, no movimento sindical, uma prática que dá brechas a essas considerações de que os operários precisam brigar com a Comissão e o Sindicato?

A segunda observação se refere ao fato de que, assim como no caso do trabalho em grupo, essa questão da transferência do conflito não deve ser vista de maneira absoluta, ausente de contradições. Da mesma forma que no grupo de trabalho há uma alternância entre a dinâmica conflituosa e a dinâmica cooperativa, não são somente críticas que os operários disparam à Comissão de Fábrica e ao Sindicato. Talvez a valorização seja até mesmo mais freqüente: os trabalhadores não se esquecem que esses órgãos são fruto de antigas reivindicações, órgãos aos quais continuam recorrendo e que se mantêm promotores e fiadores de sua luta política; foram e continuam sendo importantes nessa briga pelo direito de voz a participação ${ }^{11}$.

\footnotetext{
${ }^{9}$ Sobre a questão salarial João Augusto nos conta o seguinte: "Nós estamos aí com um problema de um dissídio de novembro para cá, agora que eles vão dar um aboninho pra dar um melzinho na chupeta. Entendeu? De novembro para cá, dá seis meses, quase sete meses (...) Aumento de dissídio, dissídio nosso era em novembro, entendeu. Então aí, não deram nada. Agora que resolveram dar um aboninho, assim, pra compensar esse período aí. Esse vazio que ficou".

${ }^{10}$ Apesar da reestruturação produtiva, alguns operários enfatizam, surpresos, que acidentes graves não deixaram de acontecer no cotidiano de trabalho: "Por isso que eu falo que naquele tempo nós tínhamos empilhadeira no setor e não tínhamos acidentes, que nem nós tivemos um último. Um ano e meio aú, nos últimos oito meses nós tivemos cinco acidentes fatais. Fatais, com vítimas, né. E antes nós não tivemos isso daí. Não deu para entender. A mudança trouxe esses acidentes" (João Augusto). "Nós passamos um ano ruim aí, um ano péssimo, foi o ano passado... O ano retrasado. Nós tivemos várias morte aqui dentro. E ninguém sabia porque que estava acontecendo essas morte. Eu não sei agora, não me lembro as morte, sei que houve três ou quatro pessoas. Nesse prédio aqui teve duas, no mesmo ano. Aquele ano foi um ano horrível. Teve a equipe lá de fora, bem aqui do lado, se você entrar nessa porta aí. O empilhador que virou a empilhadeira, ela caiu em cima dele. Aqui do lado, ali, tem uma linha de montagem que não está funcionando, mas era ônibus, só o chassi do ônibus. Estava engatado o ônibus, desligado, mas engatado. No comecinho do trabalho, de manhã, porque era fileira de ônibus né, pequenos espaços. O outro foi lá na frente, acho que ele não sabia, não reparou, pensou que estava sem a bateria. Ele mexeu na chave e estava ligada a bateria, o ônibus deu um pulo para trás e prensou o outro no outro. E o cara morreu. Teve um outro lá em baixo, no prédio 21, um companheiro, uma peça que escapou. E eu sei que o pessoal da CIPA, os cipeiro, correram, debateram, fizeram tanta reunião. A gente achava, alegava que era muita correria também né, um trabalho muito corrido e pouca gente. Na época a produção estava alta. Aí passou, acho que melhorou agora. De uns tempo pra cá melhorou bastante. Vamos ver se agora não acontece mais esse tipo de coisa, porque é tão chato, né. De repente você vem trabalhar e não sabe se volta" (Rodrigão).

${ }^{11}$ Vale a apresentação de alguns trechos sobre a Comissão e o Sindicato: "Não tínhamos Comissão de Fábrica! A Comissão de Fábrica está com uma faixa de treze anos de Comissão de Fábrica, se eu não me engano. Então, esse período antes da Comissão de Fábrica, apesar que já tínhamos Sindicatos, mas nós não tínhamos voz ativa aqui dentro, né. E hoje não, hoje tem um problema, chama a Comissão de Fábrica. Se parou a linha, aí vai negociar depois, continua a produção e a Comissão de Fábrica que é a representante nossa vai resolver o problema. Se foi discussão ou briga com a chefia, ou qualquer coisa assim né, excesso de produção ou excesso de serviço para o camarada fazer, né. Então, a Comissão vem e ela acerta isso. Mas antigamente não tinha nada disso, e era difícil" (João Augusto). Ou ainda: "Porque, até então, naquele tempo a gente não tinha direito a nada, o chefe mandava e desmandava. Hoje não. Hoje é tudo negociado. (...) Hoje o chefe não tem, aqui dentro da Empresa, ele não tem autonomia para te mandar embora. Não tem"
} 
O ponto que desejamos enfatizar não pede a ignorância ou a negação dessas observações, mas sim a consideração cuidadosa da reflexão proposta anteriormente. $O$ deslocamento do conflito de sua localização originária para o circuito fechado das relações entre operários, tende a gerar senão uma perda, uma fratura na união dos trabalhadores. Quando estavam de fato demarcadas as distinções entre chefes e subalternos - já que essas posições eram o mais puro reflexo de uma divisão entre os representantes dos proprietários e os assalariados - encontravam os operários razões para se oporem uns aos outros? Quando havia displicência na execução de uma tarefa, era o desrespeito ao trabalho do colega que contava ou seria uma forma de esvair-se e de se opor a um trabalho que não era sentido como próprio? Quando a desconsideração de direitos por parte dos patrões era evidente, não era o Sindicato o único espaço ao qual os operários sentiam poder recorrer? Quando o diálogo não era permitido, sobre o que conversavam os operários, talvez escondidos, em conspiração? Arquitetavam planos para aumentar a lucratividade da empresa ou buscavam apoio, em sua própria união, para uma luta radical que vislumbrava a conquista de poder político?

Chegamos então, naquela que julgamos ser talvez, a mais grave das conseqüências de todo esse novo processo que vem se instaurando: a diluição do sentimento de classe e o embotamento da comunidade operária. O sistema participativo, que combina comportamento cordial por parte dos chefes, despersonalização das funções de controle e supervisão e concessão de maior autonomia, autoridade e responsabilidade aos operários, dilui o sentimento de distância e assimetria entre categorias estruturalmente opostas na organização do trabalho de base capitalista. A equação ideológica, entre interesses patronais e operários, provoca um aumento da invisibilidade das contradições inerentes a um sistema que se apoia na divisão entre donos dos meios de produção e vendedores da força de trabalho e na usurpação dos segundos pelos primeiros. A fábrica se torna então uma grande e democrática organização manufatureira onde todos contam igualmente e onde as diferenças passam a se constituir individualmente, no cotidiano de trabalho, segundo o desempenho de cada um. Não há mais divergência de interesses, a não ser aquelas que se constituem em contatos pessoais e são facilmente interpretadas como fruto dos desvios morais de alguns: nada que uma conversa ou um treinamento não resolvam. Diluída de um lado pela extinção inautêntica das hierarquias, atacada de outro pela diferenciação individual por mérito, a comunidade operária se abala.

Aqui gostaríamos de dar ênfase a esse inautêntico, inconsistente, não verdadeiro. Pois não se trata de pregar a impossibilidade de uma aproximação verdadeira entre classes. $\mathrm{O}$ fato é que, nesse caso, o que está em jogo não é uma aproximação espontânea entre chefes e subalternos, que suporia exatamente o desejo de eliminação de uma desigualdade de poder e exigiria dos primeiros uma alteração de consciência, de discurso e de atitude. O que está em jogo é uma tentativa de, sem nada alterar, sustentar que não existem diferenças radicais que instauram condições bastante distintas. $O$ que se altera é a expressão superficial de uma estrutura e não a estrutura propriamente. Alteram-se o comportamento e o discurso próximos, mas não a consciência. Portanto, não se trata de uma aproximação; trata-se mais de uma negação que visa a manutenção de um determinado estado de coisas.

(Reinaldo). "(...) Porque eu acho que mudou as coisas aqui dentro a partir do momento que foi implantado o Sindicato aqui dentro, né? A Comissão de Fábrica, né? Acho que aí que mudou, né? Porque antes era tipo narcisismo, a firma mandava. Então era ela que mandava em tudo, então ela não tinha que recorrer a ninguém. Agora a firma tem que recorrer ao Sindicato. Tudo que ela tem que fazer aqui ela tem que ir atrás do Sindicato" (Júlio). 


\section{Modalidades de enfrentamento: a importância de uma história de organização coletiva}

Posto o problema que consideramos ser capaz de consequências perturbadoras para a classe operária, cabe agora matizarmos, com apoio nos próprios depoimentos, essa questão. Todo esse processo, de fundo ideológico, que visa exatamente a manutenção de uma ordem dominante, não se instaura assim de maneira tão calma e absoluta. Por um lado, não se trata da concretização de um plano maquiavelicamente arquitetado por donos de empresas para voluntariamente manter seus empregados em situação de pobreza e opressão. A história da instauração de uma estrutura de dominação é antiga, complexa e carregada de contradições. Sua manutenção depende menos de uma divisão imaginária e maniqueísta entre bons e maus e mais da construção de processos históricos multilaterais de reificação e alienação. Portanto não é o caso de simplesmente banir chefes e proprietários, mas sim de criar, através de luta e resistência, possibilidades de quebra da alienação e de ampliação da consciência.

Do lado dos operários, esse processo não dispara somente alívio, resignação e desejo de crescer individualmente por meio da competência. Gera inquietações, desconforto, desconfiança e, em alguns casos, não é capaz de abalar uma consciência e uma resistência construídas ao longo de toda uma vida e de uma história de gerações. A ideologia não se encaixa assim tão perfeitamente no pensamento e na subjetividade operária. Ela possui brechas. Brechas muitas vezes abertas por uma ligação consistente do trabalhador com seu grupo de origem, que em algum momento foi capaz de, unido, criar suas próprias representações sobre a realidade na qual estava inserido e sobre as relações que $o$ circundavam. Nesses casos, marcados por um enraizamento profundo numa comunidade, a consciência parece mais sólida e mais impermeável a conteúdos ideológicos.

Nos depoimentos que recolhemos, reconhecemos tanto a presença do que estamos denominando de um discurso ideológico, quanto momentos em que o que parece contar são representações bem próprias da experiência operária. Na maior parte das vezes, esses dois movimentos se combinam, trazendo contradições e ambiguidades que estão em grande medida presentes em todo discurso. Ao mesmo tempo, pudemos identificar três grupos razoavelmente distintos, nos quais, independentemente das contradições inerentes a uma narrativa pessoal, era possível observar a predominância de algumas concepções e atitudes. Essas concepções, por sua vez, nos pareceram ligadas à determinadas modalidades de enfrentamento à qual cada depoente parecia recorrer. Tratemos agora destas distinções e do que elas nos fazem pensar.

Num primeiro grupo, formado por operários que trabalhavam na empresa há no máximo dez anos, chamou-nos a atenção uma valorização quase que absoluta desse novo sistema. Desses depoentes, tivemos a impressão de uma certa ingenuidade, praticamente não esboçavam críticas. Nesses casos, a aderência ao discurso gerencial é bastante marcante: qualificação, treinamento, autonomia são resultado de uma abertura generosa da empresa, que a partir de uma súbita tomada de consciência, percebeu a necessidade de se instaurar novas condições de trabalho, menos insalubres. Operários e superiores não são mais pólos opostos na organização do trabalho, formam agora um time, onde todos procuram colaborar mutuamente para o alcance de um objetivo comum. A harmonia e o respeito são, para esses depoentes, as marcas do novo regime:

Problema tem. Agora, não tem problema difícil. Mas agora está sendo bem resolvido. Ficou fácil pra qualquer coisa, todo mundo se interessa um pelo outro, pelo serviço, a colaboração.

(...) No meu modo de pensar, antigamente a cabeça do pessoal era diferente, era individual. Se você, hoje, você vai no banheiro, se você não voltar até o tempo, o seu colega faz o seu serviço.

Antigamente não, ele desce. Então, quer dizer, um se preocupa com o outro. (...) Eu não tenho 
reclamação. Tudo que hoje em dia eles fazem pra você, é só pra melhorias. Ninguém está aí pra prejudicar você, hoje, no meu modo de ver (Ronaldo).

(...) Agora não, a gente tem mais diálogo. Eles pede opinião pra gente, dá opinião, ficou bem melhor. (...) No meu ponto de vista, o pessoal começou a conscientizar mais. Deram mais oportunidade. Então, eles começaram a dar abertura pra nós. (...) Porque eu acho que tudo mudou. Então, a firma está aí, está mudando, sempre renovando as coisa. Acho que é por aú, viu. Que nem eu falei, não sei se é porque tudo está mudando, então vai mudando. Então a cabeça das pessoa tem que mudar também, tem que acompanhar, né. Deve ser por causa disso aí (Edvaldo).

Eu acredito que a empresa, ela tenta cada vez mais melhorar o serviço da gente. E a gente também, né. Porque você precisa que você evite esse tipo de serviço que você faz muito esforço. Então eu acho que eles tem que mudar nessa parte. Mas eu acredito mais na empresa. Antigamente... Que nem, hoje em dia, eles se preocupa muito com a segurança da gente, em matéria de acidente, esse monte de coisa, tenta evitar. Se você está com algum problema no estrado, se não está (João Pedro).

Esses trabalhadores de fato não caem naquele mencionado maniqueísmo a que posições antagonistas mais superficiais poderiam levar: a empresa não visa realmente prejudicar sua mão-de-obra. No entanto, não é exatamente a alteração radical das condições subalternas e alienantes do trabalho o objetivo de todas essas transformações. E é aí que reconhecemos a força do chamado controle ideológico: para este grupo de depoentes não há conflito de interesses entre dirigentes e operários; não existem razões políticas, ou até mesmo mais objetivas, concretas, por trás do estabelecimento de tantas alterações. As novas relações de trabalho são fruto de um movimento de mudança natural, espontâneo, absoluto, abstrato: mudou porque tudo está mudando. A ligação entre fatos; a compreensão mais complexa, que engloba o reconhecimento de contradições; a consciência da história; os elementos concretos, enraizados na experiência cotidiana e tão característicos da fala popular: tudo isso parece ausente - ou perdido - nesses depoimentos.

Reivindicar, um termo tão conhecido pela classe operária: readquirir, recuperar, reaver o que está na posse de outrem (Dicionário Houaiss, 2001). Reivindicar perdeu seu sentido originário e tão essencial e tornou-se o ato de exigir aquilo que é necessário para que a produção transcorra eficientemente:

Nós chega, sempre nós pede, assim, quando tem reunião de [acompanhamento]. Aí a gente reivindica muitas coisas, né. A gente reivindica alguma coisa que falta no setor, o pessoal vê o que está faltando na sessão, a gente marca num papel e leva na reunião - está precisando disso, precisando disso, disso, disso. Agora já tem como você dialogar com o pessoal lá dentro, reivindicar o que está faltando no setor. Muitas vezes eles nem sabem, né. Então, tem um espaço bom, bem aberto pra: "Está faltando tal coisa, tal coisa" (Edvaldo).

Foi assim que Edvaldo nos respondeu quando the foi perguntado se ele estaria participando, atualmente, de alguma reivindicação feita pelos trabalhadores. Distorção radical: nada está sendo recuperado porque o que foi perdido não lhe pertencia. Em momento algum, mesmo que uma peça esteja fora de lugar ou faltando, ela deixa de ser da empresa e passa a ser do operário. Edvaldo não está reavendo algo que lhe foi usurpado, está recuperando um tempo perdido para a produtividade. As exigências da produtividade se tornam as suas e é por elas que ele passa a reivindicar. É assim que o descreve porque é assim que a nova forma de organizar o trabalho o faz pensar.

Em um segundo grupo de operários reconhecemos idéias bastante distintas das apresentadas acima. Esses operários, que trabalham há mais de quinze anos na mesma fábrica, não desprezam ou desqualificam as melhorias das condições de trabalho trazidas pela 
reestruturação produtiva: valorizam as alterações no espaço e nos maquinários e também confortam-se, em alguma medida, com o novo comportamento dos chefes. Entretanto, diferentemente do primeiro grupo, mencionam problemas atuais bastante objetivos (o rebaixamento salarial e a diminuição de postos de trabalho) que parecem ser também consequência do novo regime. Por outro lado, opondo-se novamente ao primeiro grupo, realizam uma análise bastante complexa - envolvendo elementos políticos e históricos acerca das razões da instauração desse novo sistema.

Como primeiro ponto, os depoentes mencionam o fato de que as mudanças na empresa foram disparadas por mudanças num contexto socioeconômico mais amplo que aquele restrito à fábrica, mudanças da organização política estatal que teriam provocado, dentre outras alterações, grande abertura do mercado para instalação de empresas internacionais em solo brasileiro. A partir de então, a empresa em questão teria sofrido uma crescente perda de mercado em função da forte concorrência com novas montadoras que começavam a habitar o circuito nacional e teria se visto obrigada a reelaborar toda sua estratégia de produção e comercialização para se manter competitiva. Relatam Reinaldo e João Augusto:

Então, conclusão: hoje não. Hoje ela já tem concorrência. Essa concorrência do mercado também fez com que ela mudasse, porque pra ela segurar o mercado dela, ela também teve que mudar. (...) Por necessidade da própria empresa. Da própria empresa. Porque a maneira de negociar é outra, a necessidade de preparação do pessoal pra a firma também é outra. Pela concorrência de mercado. Ela tem que ter um pessoal mais preparado. Então, conclusão: a necessidade dela se manter no mercado, com qualidade, com produto bem aceitado pelo público. E pra isso ela teve que mexer em tudo. Tudo! Desde qualidade do produto até o pessoal, até na mão-de-obra. Então, a necessidade da mudança, foi a mudança do próprio tempo também. Senão, não funciona. Senão ela sabe que ela dança. Jamais... No mínimo fecharia (Reinaldo).

Ah... Essas mudanças vem por causa da competitividade que eles não tinham antigamente. Antigamente eles eram os donos do mercado, entendeu? Acho que uns $80 \%$ do mercado era deles. Então, depois começou a aparecer outras empresas chegando bem junto mesmo. Isso acarretou... Teria que mudar mesmo (João Augusto).

Há, nessas observações, a convicção de que a reestruturação produtiva responde prioritariamente aos objetivos da própria empresa. Para este grupo de trabalhadores, a intenção final e específica do processo de mudança nunca foi, exclusivamente, a humanização do trabalho no chão-de-fábrica. Havia um interesse muito claro por trás dos benefícios proporcionados pela nova organização e, se o trabalhador obteve vantagens, foi porque vantagens para os trabalhadores significavam vantagens para a empresa.

Isso aqui que você vê hoje, o filme que vai passar, chamando a turma, tentando mudar a consciência da turma, do pessoal, do empregado hoje em dia... Tudo é interesse dela. Tudo é interesse dela. Nós temos, levamos alguma vantagem nisso? Levamos sim. Porque hoje em dia, vamos supor, um setor igual aquele nosso ali: se você passasse ali há dez anos atrás, se você ver fotos, um exemplo: você entrando lá no pavilhão, tem umas fotos, logo que você entra, do lado direito, 'antes e depois'. (...) Então, tudo mudou, vamos dizer assim, em cima de interesses. Interesses logicamente da Empresa (Reinaldo).

Antes, na minha época, quando eu entrei aqui, a firma não dava tantas oportunidades. Antes, mais ainda, era pior: o cara não podia estudar. Agora não. Com a implantação de trabalho novo, essas palestras, eu acho que a firma chegou a uma conclusão que ela tinha que investir no trabalhador. Por quê? Porque ela chegou à conclusão que o operador treinado produz mais, é consciente, procura não faltar no serviço. Em troca ela dá o treinamento, o conhecimento. No meu caso tudo bem, eu estou com quarenta anos, se eu sair daqui provavelmente não vou 
ter muita oportunidade de trabalhar numa outra firma. Mas tem muitos jovens que tem, né. Então, uma pessoa assim, ela faz melhor treinar. Se por acaso não der certo, ninguém tem emprego assim a torto e a direita. Se ele recebe o treinamento que a firma dá, ele tem mais chances (...) Então, vale a pena você entrar naquilo que a firma põe como desenvolvimento. Porque, na verdade, tudo bem, ela visa ela, treinar bem o funcionário é bom prá firma, mas também é bom para o operário, para o funcionário (Josias).

Eles querem implantar porque... Se for só prá melhorar a vida do peão também eu acredito que não é. Não iria ser... Eu sou realista. Se for só pra melhorar a vida do peão, eu acho que não seria implantado. Porque quando é implantada uma coisa dessas, é porque existe dois ganhos. Acredito eu, que seria o ganho material, ganho financeiro deles, e o ganho humano da pessoa, reciclagem do ser humano. Eu penso por esse lado. Porque se você dá uma condição boa pra uma pessoa trabalhar, quem que não trabalha mais contente? (José).

Notamos nesses depoentes a clara percepção de que o que ocorreu não foi uma mudança estrutural que visasse o desmantelamento da forma de organização capitalista; a reestruturação produtiva não possui como objetivo o rompimento da dicotomia entre os donos do meio de produção e os vendedores de força de trabalho. Trata-se talvez de uma troca - mais autoritariamente imposta do que democraticamente instaurada - entre empresários e trabalhadores: a empresa fornece condições de trabalho comparativamente melhores, treinamento, conhecimento e qualificação e ganha maior produtividade e qualidade. $\mathrm{O}$ trabalhador sente-se menos explorado, mais digno e qualificado para competir no mercado caso venha a perder seu atual emprego, enquanto os empresários vêem satisfeitos, seus lucros crescerem e se estabilizarem. Se não nos detemos em considerações mais profundas, o que vemos - o que a aparência quer mostrar - é isso: é bom para empresa e é bom para o operário.

No entanto, esses depoentes não parecem manter-se nesse registro: reconhecem artificialidade no chamado sistema participativo e colocam em questão o uso da palavra troca para definir o que acontece entre empresa e trabalhadores. Não há troca porque não há igualdade. Para esses operários, está claro que as sugestões devem ser obrigatoriamente aceitas - vale a pena entrar naquilo que a firma põe como desenvolvimento -, porque ficar sem emprego não é uma opção a ser escolhida entre tantas outras; ficar sem emprego é não poder manter a própria vida. São eles que nos falam, saudosistas, de um distante metalúrgico dos anos 80 , que desapareceu e não voltará a existir e queixam-se cansados da presença de uma pressão incessante para que haja mudança de comportamento em direção a uma constante qualificação e requalificação.

Então, naquela época lá, os meninos saíram da escolinha e não tinha onde pôr. Puseram lá e lá estava precisando de gente. Encheu de moleque lá. Eu fui lá ver os menino trabalhar. Aí eu falei pro moleque assim: "Por que você está encarando a linha?", "Ah, meu pai falou prá mim que eu tenho que agüentar as pontas aqui até melhorar a situação". Hoje em dia um é técnico já. E o outro já está andando pra lá e pra cá com uma pranchetinha na mão... Entendeu? Então, eles agüentaram a barra ali, sobreviveram. Estão na empresa, já estão no caminho que eles queriam. Então, tem tendência, tem espaço. E aqueles que não querem, vai ficar na produção. Mas só que a produção também fica apertando. Vai acabando com esse metalúrgico dos anos 80. Acabando. Aquela coisa que você via na televisão, você chegou a ver? Então, não existe mais e nem vai existir mais. Porque nós estamos na era da conversação, do diálogo. Não adianta mais. Não tem mais greve (João Augusto).

As formas de trabalhar e se portar no interior da fábrica hoje são outras: se há aceitação de tudo que é proposto, há manutenção do emprego. Emprego cada vez mais satisfatório para aqueles que vestem a camisa da empresa. Ganha-se bônus por sugestões inteligentes, por produção rápida e qualificada. Não há mais espaço para reivindicação e 
greve. Tudo é conversa e conciliação. Se há pelo que reivindicar, não há vontade maior do que a vontade de manter um emprego satisfatório em época de vacas tão magras. Antes não havia opção: era luta ou morte gradual no chão de fábrica. Hoje há cada vez menos razões para lutar. Ser um bom operário no passado não fazia diferença, hoje acumula benefícios. A desigualdade e a exploração é cada vez mais encoberta por chances individuais de melhores condições de vida, chances que não parecem precisar de revolução para serem alcançadas, mas apenas de bom comportamento.

Isso é o que nos conta esse grupo de operários, em tom desanimado mas ao mesmo tempo crítico e sufocado. Para eles, a nova organização do trabalho não traz somente melhorias, instaura também novos problemas e novas exigências e não elimina o princípio fundamental de um trabalho insalubre: a desigualdade de poder. Esses depoentes nos falam sobre o diálogo e a negociação - tão valorizados como uma das maiores conquistas do novo sistema - de maneira ambígua e pouco comemorativa. Ao mesmo tempo em que não desejam reviver a truculência do passado, as negociações lhes parecem permeadas pela apatia e pela falta de delimitação de diferenças; são mecanismos menos violentos, mas que por vezes mascaram a distância e a diferença e criam uma falsa harmonia. Ao contrário, as greves são lembradas como momentos de imposição e de demarcação de limites e exigências de um grupo composto a partir de afinidades concretas e reais. Brigas explícitas, paralisações explosivas, greves radicais são coisas de que esses depoentes se ressentem exatamente porque ainda reconhecem uma divergência de interesses entre eles e seus patrões. A despeito dos traumas e riscos que estas situações podem gerar, elas representam a expressão de um conflito e de uma dor vividos cotidianamente - mesmo depois da reestruturação produtiva. Para esses operários ainda há razões para lutar, os parceiros é que parecem distantes, perdidos, seduzidos pelo emprego garantido e pela chance de "ascensão" individual.

Encontramos ainda um terceiro grupo de depoentes, intermediário relativamente aos dois apresentados anteriormente. Trata-se de um grupo no qual reconhecemos um tipo de compreensão próxima à apresentada pelo segundo grupo, mesclada a um comportamento semelhante àquele percebido no primeiro grupo. Ou seja, são operários que reconhecem na reestruturação produtiva um pacto entre a empresa e os operários, de modo que estes últimos, mais satisfeitos, contribuam para a manutenção de uma organização que não pretende beneficiar ambas as partes igualmente. Mas, ao mesmo tempo, estes depoentes não se mostram dispostos a entrar em desacordo com as novas diretrizes nem mesmo desejam reencontrar experiências passadas de reivindicação; preferem assimilar as novas exigências e aproveitar, como podem, as concessões proporcionadas pelo atual sistema. São trabalhadores, que a despeito da consciência da desigualdade e da exploração, parecem profundamente marcados pelo medo de perder o pouco que possuem e pelo sentimento de que qualquer resistência mais ativa será sempre em vão. $O$ que neles predomina é a percepção de que condições estruturais, historicamente forjadas, jamais poderão ser alteradas: as forças sociais dominantes são poderosas demais. É o que reconhecemos no depoimento de José, um trabalhador que conhece as regras do jogo e nelas se apóia para sobreviver:

(...) Nós chegávamos a trabalhar em três, quatro, cinco máquinas por dia. Naquela época era um absurdo. Hoje em dia é normal, mas antigamente era um absurdo. A gente trabalhava em três, quatro, cinco, seis, dependendo do dia. Fazia um pouquinho aqui, um pouquinho ali. E aí a gente vai sempre lutando pra... Porque acontece o seguinte, não existe proteção. Eu sempre fui uma pessoa que nunca tive proteção. E como eu não tenho proteção, eu sempre procurei fazer a minha parte bem feita, com o mínimo de erro possível. Pra você não deixar falha pra trás. Então, eu procurava cumprir minha obrigação e até hoje eu estou aqui fazendo. (...) Eu tenho esse tempo de casa e eu nunca enfrentei problema com chefia. Porque eu procuro fazer minha parte. Porque eu acho que se você encontra um problema diferente, é porque você dá motivos. Se você não der motivos, você não encontra obstáculos. Eu sempre procurei cumprir 
minha parte direitinho e, graças a Deus, hoje eu não tenho do que reclamar e ninguém reclamar de mim (José).

Como já é perceptível pela descrição das concepções predominantes, identificamos, em cada um desses três grupos, diferentes atitudes, que se configuram para nós como maneiras distintas de responder aos problemas que advêm dessa nova forma de organização. É aí que observamos a presença de modalidades de enfrentamento ou de resistência. O primeiro grupo nos surpreendeu, em alguma medida, pela ausência de uma postura crítica e de alguma atitude que denotasse exatamente o reconhecimento de problemas e contradições: para esse grupo, a reestruturação produtiva surge de maneira abstrata, sem determinações históricas, como algo que responde às necessidades operárias e vem instaurar a harmonia e o equilíbrio no cotidiano de trabalho. Esses depoentes nos parecem profundamente marcados pelo controle do discurso ideológico, contra o qual não encontram elementos para se opor.

Diferentemente, o segundo e o terceiro grupo mantêm a oposição entre os seus interesses e os da empresa, marcando uma diferença entre aquilo que o discurso da reestruturação produtiva pretende informar e o que os operários dele assimilam: do ponto de vista desses depoentes, o sistema toyotista não se caracteriza pela quebra das hierarquias e pela participação livre e espontânea dos operários, mas sim pelo remodelamento de padrões antigos, que mesmo trazendo benefícios, mantém sua estrutura originária. Entretanto, mesmo apoiados em concepções semelhantes do processo, as atitudes de enfrentamento desses dois grupos se distinguem: enquanto o segundo grupo deseja reencontrar posições de resistência mais ativas e contundentes, o último grupo de depoentes prefere manter uma espécie de resistência interior, considerando os problemas e as contradições do sistema, sem no entanto participar de qualquer movimento de oposição que vise a alteração das atuais condições.

Os limites entre esses dois últimos grupos são tênues, porque afinal ambos não se propõe de fato a retomada de posições mais radicais e desafiadoras. Ameaçados pela intensa onda de desemprego e acuados pela força da nova organização, a resistência permanece em grande medida no âmbito do discurso ou deslocada para a organização sindical, que por vezes parece distante. A diferença entre esses dois grupos talvez se torne mais visível pela consideração dos sentimentos que permeiam as narrativas: as opiniões do segundo grupo relativas à nova forma de trabalhar são marcadas por um crescente desânimo, que chega a beirar uma tristeza profunda e se opõe à alegria e à vivacidade das descrições do movimento operário dos anos 70 e 80 . Esses depoentes têm esperança de reencontrar uma experiência de resistência que para eles se mostrou mais autêntica e radical; uma experiência que visava de fato a quebra da estrutura vigente. Por outro lado, os depoentes do terceiro grupo não acreditam que possam viver uma situação mais vantajosa do que esta que vem sendo proporcionada; neles não conta tanto o desânimo, mas sim o desejo quase desesperado de se apropriar e de fazer suas as conquistas e os benefícios da reestruturação.

\section{Desenraizamento reinstaurado e "reinventado"}

Evidentemente, sabemos que as atitudes de resistência se constroem através de processos bastante complexos, que levam em conta, entre outras coisas, a história individual de cada sujeito, as influências e os contextos aos quais ele se viu ligado. Não somos capazes de apresentar aqui uma discussão bastante embasada a respeito desse fenômeno, mas é exatamente com relação a esse ponto que gostaríamos de introduzir uma hipótese, com apoio nos depoimentos por nós recolhidos. Notamos que os operários, que em nossa opinião 
apresentavam considerações bastante complexas e críticas, além de exigências mais radicais com relação à nova organização, eram aqueles operários que trabalhavam na fábrica há pelo menos quinze anos e tinham tido a chance de participar do movimento operário dos anos 70 e 80, o chamado novo sindicalismo. Na outra ponta, os trabalhadores dotados de menor consciência crítica, eram trabalhadores que, se não trabalhavam há poucos anos na fábrica, não tinham tido certamente um contato mais profundo com a experiência passada de organização. A partir do estabelecimento dessa relação - entre experiência passada e consciência e atitudes atuais - e do reconhecimento da vulnerabilidade de alguns operários ao discurso ideológico, aproximamo-nos de uma consideração que nos pareceu contundente: os processos envolvidos na reestruturação produtiva podem abalar exatamente uma das fontes de alimento da resistência - o enraizamento numa comunidade.

Aqui nos apoiamos num conceito proposto por Simone Weil (1943/1996), que define o enraizamento como a necessidade que todo ser humano possui de ter "uma raiz por sua participação real, ativa e natural na existência de uma coletividade que conserva vivos certos tesouros do passado e certos pressentimentos do futuro" (p. 411). Foi também Simone Weil quem focalizou a arrasadora experiência de desenraizamento vivida pela classe operária, que submetida à reificação e ao trabalho alienado, viu-se arrancada de sua humanidade, transformada em "um pouco menos que uma coisa".

É exatamente esta terrível experiência de desenraizamento que o movimento operário de outrora parece ter sido capaz de combater. Ao se organizarem de maneira autônoma (desligados dos mecanismos de negociação legalmente instituídos), ocupando empresas e fazendo-as funcionar de maneira não hierarquizada, os operários se mostraram capazes de, coletivamente, realizar "uma alteração das relações sociais de trabalho e de produção" (Bernardo, 1996, citado por Antunes, 1999). Nesse momento, em que unidos, os trabalhadores visavam o controle social dos meios materiais do processo produtivo, estava restituída a possibilidade de uma participação real, espontânea e não servil. Foi essa experiência que pôde proporcionar uma suspensão, mesmo que breve, do desenraizamento operário; suspensão que não veio de um acordo entre patrões e subalternos, mas sim de uma atitude e de uma organização revolucionárias por parte dos próprios trabalhadores.

Entretanto, essa experiência não se consolidou, dissolveu-se e deu brechas para uma reorganização da ordem estrutural dominante. $O$ sistema toyotista não visou somente restabelecer os antigos padrões de produção, apropriou-se também das habilidades organizacionais de que os trabalhadores se mostraram desejosos e capazes. Implantou-se portanto aquele sistema de participação e colaboração que, como já vimos, gera maior produtividade e manipula o trabalhador de forma a deslocar os conflitos para o interior do próprio grupo de operários. Através deste conjunto de estratégias, a reestruturação produtiva proporciona uma falsa experiência de participação e parece reinstaurar o desenraizamento, sob outros moldes, talvez ainda mais problemáticos.

O desenraizamento está agora menos visível porque seu antídoto - a participação está sendo aparentemente concedido. Envolvidos por um ilusório enraizamento, por uma artificial inserção numa coletividade, os operários perdem de vista suas próprias razões e necessidades, distanciam-se uns dos outros e não reconhecem mais aquela exigência de unirem-se para lutar por um objetivo comum, porque esse objetivo está diluído em meio à crença imposta de que tudo mudou. Abalada a comunidade, a resistência míngua, abatida, impotente, sustentada somente por quem se alimenta das lembranças de um tempo em que uma outra realidade foi de fato vislumbrada. Só quem pode se apoiar no passado é capaz de enxergar o novo mundo com seus próprios olhos, é capaz de interpretar a situação atual a partir de seu ponto de vista, de sua experiência, de sua história e da dos seus. Quem não teve a chance de viver um enraizamento autêntico não tem condições de se amparar na esperança de uma alteração radical, está vulnerável à concepções que lhe são apresentadas para 
explicar o que acontece a si mesmo. "Quem é desenraizado, desenraíza" (Weil, 1996, p. 415). Quem poderia enraizar, luta contra o embotamento ideológico para encontrar parceiros; luta ao mesmo tempo contra a ameaça do desemprego e contra a submissão à sedutora nova organização. Cansados. Quase resignados.

Exatamente porque este artigo encontra-se apoiado sobre depoimentos de operários, ele não pretendeu realizar uma desvalorização absoluta do processo de reestruturação produtiva, mas sim problematizá-lo e talvez focalizar aquela que julgamos ser uma perturbadora conseqüência: o restabelecimento do desenraizamento, agora camuflado e negado.

Changes in the workplace, worker struggle and rootlessness: the re-structuring of production techniques in the day-to-day lives and representations of work of metalworkers in a company located in the $\mathrm{ABC}$ region of São Paulo

In this article, the different ways in which the re-structuring of production techniques are perceived by workers deeply affected by such transformations are described and analyzed. A case-study methodology of research and analysis was utilized. After preliminary visits to the target company, a field research diary was elaborated and 13 workers were interviewed. The subsequent analysis revealed that: 1) The re-structuring of production techniques is understood in different ways and provokes different feelings (relief, need for further elaboration, mistrust) in those interviewed; 2) Workers do, in fact, seem to place great value on some of the changes introduced into the workplace environment; 3) The reorganization of the factory environment, which is often accompanied by a seductive ideological discourse, disguises structural contradictions and renders the perception of worker insatisfaction difficult; 4) The so-called "participative system" seems to mask an internalized symbolic control, creating the illusion of a convergence between worker and company interests. The re-structuring of production techniques provokes a weakening of feelings of class solidarity and a blunting, in the workers, of the perception of community, which saps, in turn, the power of resistance and increases feelings of worker rootlessness; 5) Workers use different techniques of resistance, which in turn seem to be related to their diverse life histories - and especially to their ties to labor organizations.

Keywords: re-structuring of production techniques, metalworkers, worker struggle, rootlessness, ideology.

Endereço para contato com a autora: alimccaffrey@yahoo.com

Manuscrito recebido em: 07/08/2003 Aprovado para publicação em: 11/09/2003

\section{Referências bibliográficas}

Antunes, R. (1999). Os sentidos do trabalho: ensaio sobre a afirmação e a negação do trabalho. São Paulo: Boitempo.

Bernardo, J. (1996). Reestruturação capitalista e os desafios para os sindicatos. Lisboa. [mimeo.] 
Bresciani, L. P. \& Oda, N. T. (1996). Inovação tecnológica, mudança organizacional e negociação coletiva: o panorama brasileiro e o caso do complexo automotivo no ABC. Caderno Técnico (SESI/CNI), 22, 42-51.

Chaú, M. (1979). Cultura do povo e autoritarismo das elites. In A cultura do povo. São Paulo: Cortez \& Moraes e Educ.

Corrêa, M. B. (1997). Reestruturação produtiva e industrial. In A. D. Cattani (Org.), Trabalho e Tecnologia: Dicionário Crítico. Petrópolis: Vozes.

Dicionário Houaiss da Língua Portuguesa (2001). Verbete Reivindicar (p. 2420). Rio de Janeiro: Objetiva.

Ferro, J. R. (1990). Aprendendo com o Ohnoísmo (produção flexível em massa): lições para o Brasil. Revista de Administração de Empresas, 30 (3), 57-68.

Trist, E. (1978). Uma crítica Sócio-técnica à Administração Científica (A. M. Rodrigues, trad.). São Paulo. [digitado]

Weil, S. (1996). O enraizamento. In E. Bosi (Org.), A condição operária e outros estudos sobre a opressão (p. 411). Rio de Janeiro: Paz e Terra. (Originalmente publicado em 1943) 